\title{
Editorial
}

\section{International collaboration in clinical chemistry and laboratory medicine: the Human Proteome Organization (HUPO) Plasma Proteome Project}

The Human Proteome Organization (HUPO) was founded in 2001 to accelerate the development of the field of proteomics and to stimulate and organize international collaborations in research and education (1). HUPO has launched several major initiatives, of which the Plasma Proteome Project (PPP) is the most salient for clinical chemistry and laboratory medicine (Figure 1).

The PPP has three long-term goals: (i) comprehensive analysis of the protein constituents of human plasma and serum; (ii) identification of physiological, pathological and pharmacological sources of variation within individuals over time, leading to validated biomarkers; and (iii) determination of variation across individuals and across populations due to genetic, nutritional, lifestyle and other factors.

Blood samples have the special advantages of being highly accessible sources of new human specimens, being available in large, already-existing specimen banks, and capturing proteins secreted or shed by cells in every organ of the body. The expertise of the clinical chemistry/laboratory medicine fields is highly valued. With the power of modern proteomics methods to identify and directly or indirectly quantify large numbers of proteins simultaneously, it is now possible to explore and characterize protein molecular signatures diagnostic of specific diseases and treatment responses (2-5). Hopefully, this work will overcome the recent paucity of new blood tests with high clinical value (6).

From a planning process that began with two workshops and then the 1st HUPO World Congress on Proteomics in Versailles in 2002, the Plasma Proteome Project Pilot Phase emerged to address the following technical and scientific questions:

1. What standard operating procedures for collec-

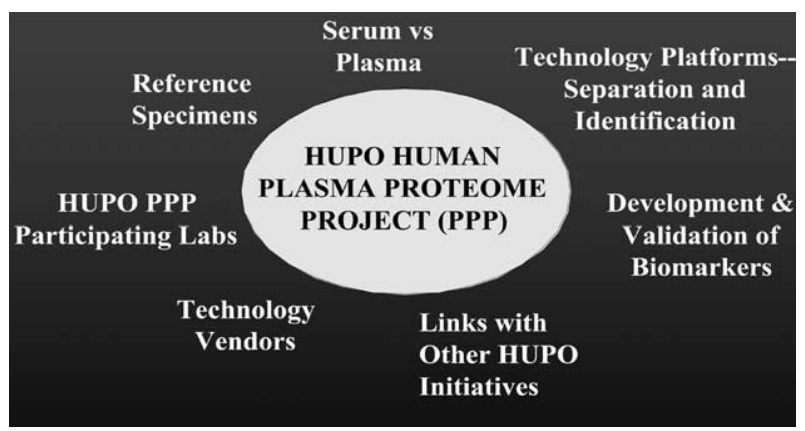

Figure 1 Scheme showing aims and linkages of the HUPO Plasma Proteome Project. tion, handling, storage and thawing of specimens are best suited to proteomic analyses with various technology platforms?

2. How should one choose whether to collect either serum or plasma? If plasma, citrated, EDTA or heparin-anti-coagulated?

3. What is the sensitivity of various techniques to detect and identify proteins over the huge dynamic range of concentrations in the circulation?

4. What are the advantages and disadvantages of depleting or pre-fractionating the most abundant several proteins?

5. How should proteins that are visualized and identified be enumerated and categorized, with special attention to post-translational modifications and tissue of origin?

6. Which method leads to more protein identifications - separation of intact proteins or digestion first, then separation of peptides?

7. What are the advantages and limitations of gelbased vs. liquid phase multi-dimensional separation methods? Of various mass spectrometric methods? Of specific chemical labeling to create subproteomes?

8. How can separation methods best be linked in high throughput with mass spectrometry?

9. What are the comparative costs of various separation and analysis schemes?

In order to compare the attributes of various technology platforms, reference specimens are essential, and are a well-established practice in clinical chemistry/laboratory medicine. The PPP Specimens Committee chose the following:

(a) A lyophilized citrated plasma (1 $\mathrm{ml}$ ampoules) prepared from 25 donors by the UK National Institute of Biologics Standards and Control (NIBSC) for the International Society for Thrombosis and Hemostasis/Standards Committee.

(b) Sets of four frozen reference specimens, prepared for PPP by BD Diagnostics (Franklin Lakes, NJ, USA) from male/female pairs in three different ethnic groups (Caucasian-, African-, and Asian-Americans), provided as four $250 \mu \mathrm{l}$ aliquots of each.

(c) The Chinese Academy of Medical Sciences set of four serum and plasma specimens from Chinese in Beijing, according to the BD protocol (four aliquots each).

These specimens were shipped to the 47 participating laboratories in 13 countries requesting to run 
the reference specimens in a very broad array of technology platforms (7). Quantitative immunoassays of 39 proteins have been performed to provide a calibration curve over 7 orders of magnitude for these proteins. A PPP database repository has been created by the European Bioinformatics Institute and the Bioinformatics Core at the University of Michigan.

Preliminary data were presented at the HUPO 2nd World Congress on Proteomics in Montreal in October 2003; extensive analyses by individual laboratories and across laboratories, specimens and technology platforms will be reviewed and elaborated at a "jamboree" workshop in June 2004. Pilot Phase data will be made publicly available through the www.hupo.org and PPP websites. Results will be presented in detail at the 3rd World Congress on Proteomics in Beijing 23-27 October, 2004 and published shortly thereafter. Meanwhile, planning will begin on application of the findings from the Pilot Phase to large-scale, disease-oriented population cohorts across major ethnic groups.

The PPP leadership includes the following committees (chairs): Specimens (Daniel Chan, Johns Hopkins, Baltimore); Technology and Resources (Richard Simpson, Ludwig Institute, Melbourne); Database and Bioinformatics (Henning Hermjakob, European Bioinformatics Institute, Cambridge, and David States, University of Michigan, Ann Arbor); Population Cohort Studies (Gerard Siest, Nancy, France); Education and Training (Peipei Ping, UCLA, Los Angeles); and Exec- utive Committee (Gilbert Omenn, University of Ann Arbor, Michigan).

\section{References}

1. Hanash S, Celis JE. The Human Proteome Organization: a mission to advance proteome knowledge. Mol Cell Proteomics 2002;1:413-4.

2. Adkins JN, Varnum SM, Auberry KJ, Moore RJ, Angell $\mathrm{NH}$, Smith RD, et al. Toward a human blood serum proteome: analysis by multidimensional separation coupled with mass spectrometry. Mol Cell Proteomics 2002;1:94755.

3. Pieper R, Gatlin CL, Makusky AJ, Russo PS, Schatz CR, Miller SS, et al. The human serum proteome: display of nearly 3700 chromatographically separated protein spots on two-dimensional electrophoresis gels and identification of 325 distinct proteins. Proteomics 2003;3:1345-64.

4. Hanash S. Disease proteomics. Nature 2003;422:226-32.

5. Liotta LA, Ferrari M, Petricoin E. Written in blood. Nature 2003;425:905.

6. Anderson NL, Anderson NG. The human plasma proteome: history, character, and diagnostic prospects. Mol Cell Proteomics 2002;1:845-67.

7. Omenn GS. The Human Proteome Organization Plasma Proteome Project Pilot Phase: reference specimens, technology platform comparisons, and standardized data submissions and analyses. Proteomics. May 2004.

Gilbert S. Omenn MD, PhD , University of Michigan, Ann Arbor, MI 48109-0656, USA

Phone: + 1 734-763-7583, Fax: + 1 734-647-8148,

E-mail: gomenn@umich.edu 